\title{
Marketing Evaluation of Public Transport Quality Attributes: Review of Two Waves of Research
}

\author{
Roman Sidorchuk \\ Irina Skorobogatykh
}

Department of Marketing, Plekhanov Russian University of Economics, Moscow, the Russian Federation

Email: Sidorchuk.RR@rea.ru

Doi:10.5901/mjss.2015.v6n3s3p275

\begin{abstract}
Marketing activity in the sector of public transport (PT) is focused on the development of alternative to private cars use. Creation of this alternative requires development and delivery of value propositions to private cars' owners. Such value propositions should be significant to the owners and lead to switch to public transport use. The paper is designed to promote better understanding of possibilities and limitations of attributes, which define PT quality aspects focused on the attraction of private cars' users. We carried out two waves of research based on the methodology of parametric indicators use. Attributes under study are the following: cleanliness in PT, ticket sale speed, availability of cellular communication signal, availability of WiFi, availability of navigation tools in PT, etc. Findings allowed drawing the following conclusions: characteristics of PT service indicators can be improved based on regular researches; increase in PT service quality didn't lead to decrease in private cars number; it's necessary to carry out the analysis of private cars' owners' values to find out value propositions significant to them and consequently leading to shift to PT use.
\end{abstract}

Keywords: marketing, public transport, Moscow, quality of services, customers' satisfaction

\section{Introduction}

Marketing mission and objectives are ambiguously perceived in academic literature and business practice. It's especially difficult to define marketing place in the sphere of state services and in the sphere of public services subject to public regulation. One of these spheres is the sphere of public transport (PT). The process of deregulation doesn't affect this sphere yet. Particularly, in Moscow one of important aspects that prevent PT deregulation is traffic jams issue.

Historically traffic infrastructure of Moscow was determined by the primacy of public transport, as a result constraint of parking space became one of the most important outcomes. Moreover, the "old" part of the city within the Third ring road prevents principal widening of existing or building new traffic arteries. Specified problems are accompanied by significant growth of private motor transport number. According to "Region rating by the number of cars per 1000 residents" (Region rating by the number of cars per 1000 residents is made, 2014) the growth of private cars in Moscow over 2013 made up 4,7\%. Automobile lending programs play a key role in this phenomenon. In Moscow and the Moscow region mostly young people aged 25-35 use consumer loans for private car purchase. As a rule, they are managers and specialists, who are active drivers and spend much more time driving than adult drivers. In addition, over the period of 2006 - 2013 in the region adjacent to Moscow a large number of accommodations were built. Owners and families of those accommodations prefer to work and spend spare time in Moscow that exercises significant influence on automobile traffic state (the growth of cars number in the Moscow region over 2013 made up 5,4\%). All the above mentioned lead to traffic jams. Based on the results of The world capital of traffic jams (The world capital of traffic jams, 2014) research review, average congestion level of common streets in Moscow in 2013 was 66\%, in case of high roads this indicator was equal to $63 \%$. During rush hours time delay in a traffic jam is 74 minutes on the basis of one-hour path. According to the estimate of the head of Department of Transportation and Road Transport Infrastructure Development of the city of Moscow Liksutov M. (Liksutov M., 2014) permissible quantity of cars on Moscow roads is exceeded by almost 500 thousand. The heaviest day for driving in Moscow is Tuesday both in the morning and in the evening. On this day the capital's traffic network is congested by $120-160 \%$.

The above-mentioned circumstances became a prerequisite to the need for PT research based on some parametric indicators analysis. Research client is public institution "Organizator perevozok" of Moscow city (based on tender won by Federal State Budgetary Educational Institution HVE Plekhanov Russian University of Economics). 
Additional scientific base is results of the study carried out by the professors of Marketing Department (Sidorchuk et al., 2015), based on internal grant of Federal State Budgetary Educational Institution HVE Plekhanov Russian University of Economics over the period from June 23 to July 11, 2014 in Moscow.

Study hypothesis proposed by the client suggested that control over a number of significant parametric indicators of PT transport services quality will allow due to their improvement promoting private transport users' shift to public transport.

\section{Literature Review}

In the area of public management and regulation marketing has been used relatively recently, and in some countries, for example, in Russia there's no complete theoretical basis for its application yet. However if there's a plan to include marketing in the system of interaction with public services' consumers, significant problems appear. For example, in "Marketing in the public sector" Kotler P. and Lee N. (Kotler P. \& Lee N., 2006) state that "one of the area's most ignored and misunderstood by employees of public sector is marketing. Not having knowledge of marketing is equivalent with not making marketing studies, with not defining your customers, partners and competitors, with no segment, not picking a target and not defining your service offer, with not dealing with the requesting process of innovation and launching new services, with not identifying new distribution channels for public service, with not setting a fair price for these services when the institution needs to recover part of their supply costs, with not speaking about them clearly and convincingly". At this point it should be noted that we use the definition of American Marketing Association (American Marketing Association, 2013): "Marketing is the activity, set of institutions, and processes for creating, communicating, delivering, and exchanging offerings that have value for customers, clients, partners, and society at large." In the Soviet Union and in Russia marketing as a concept and classroom discipline appeared at the end of 1980-s due to economical reforms (perestroyka). However, the term and understanding of marketing existed in the USSR before, considering that in 1976 a marketing section under the Chamber of Commerce and Industry of the USSR was created. Members of this section propagandized marketing knowledge being lecturers, writers of articles that were published in "Marketing" collections. Besides, the section of marketing contributed significantly to formation of professional associations: Russian Marketing Association, Russian Association of Managers, and also to development of educational standard for professional marketing specialists training for Russian market (Fox K. F. A., Skorobogatykh I. I. \& Saginova O. V., 2005). Despite the rapid and wide spreading of understanding marketing in Russia from the period of perestroika, aggressive interest on the part of commercial companies in marketing conception and managers' advanced training, particularly due to selfeducation and reading more marketing books appeared in Russia over the period of 1990-2000, the use of marketing, its use experience in the area of public services rendering are extremely poor. (Fox K. F. A., Skorobogatykh I. I. \& Saginova O. V., 2008).

The analysis of literature provides us with "rich soil" to confirm this definition applicability in the area of public services, but applicability of marketing in the sphere of PT regulated by government is of particular interest to us. We are going to use consumer's satisfaction as a base marketing notion for PT services estimation. In terms of marketing satisfaction is understood as feeling of content the consumer has, who compares preliminary expectations and actual qualities of purchased product (Evans M., Jamal A. \& Foxall G., 2006). Thus, satisfaction is closely related to quality. Quality is the best and most complete indicator, which measures effectiveness of transport system (Nevfela Jifi, 2008; Tobias et. all, 2009). In its turn, quality depends on competition and some studies show (lancu, 2010) that choice between various modes of transport creates competition between them that makes the work more marketing-demand in the sphere of PT. In this respect it should be noted that PT service consumers' value expectations are primarily related to providing cheap and reliable transport services (Costa A. \& Fernandes R., 2012).

An important issue, which defines assumed efficiency of our study, relate to the question of impact of various attributes of PT transportation on private cars' owners for their shift to PT use. There's no unanimous opinion in literature. On the one hand, we can present Steg's position (Steg L., 2003) that positive perception of public transport can promote to city residents' switch from private cars to PT. One may assume that such positive perception will be provided by PT services quality. In this case when managing PT services quality it's possible to use the integral effect by the analogy with loyalty programs (Sidorchuk R., 2014). However, some studies prove that services quality isn't always relevant to consumers' satisfaction (Friman M. \& Felleson M., 2009). It may create a situation when quality increase in PT services won't lead to the desired result - increase in private cars' owners' satisfaction with PT services. On the other hand, studies conducted by Webb (Webb V., 2010) show that service quality and clients' satisfaction influence the degree of loyalty to public transport. However, the issue of whether increase in loyalty to PT leads to its higher usage frequency by private cars' owners is left out of consideration. Considering that perception of quality is subjective and based on users' 
lifestyle and transport behavior (Dragu V., 2004; James S., 2001; Raicu S. \& Dragu S., 2012), quality increase of PT services might not affect private cars' owners' behaviour, since they lack or have minimal experience of PT use. It is indirectly proved by the studies of satisfaction with PT operators' work, which according to Anastasie (Anastasie D., 2012) is defined by quality of rendered services based on its evaluation by passengers. If private cars' owners aren't passengers of PT, they cannot evaluate the quality of services provided by PT.

Another important to our study aspect of PT services evaluation is choice of attributes. Literature lacks unanimity regarding estimation of some or other attributes' significance for PT services perception by passengers. Some studies (Stopher P. \& Jones P., 2003) mention that quality of transport service covers not only quality of service in transport terminals and transport facilities but passengers' comfort during transporting. Other researchers distinguish punctuality/reliability of services (König A., 2002). In some studies authors (Eboli L. \& Mazzulla G., 2009) put an emphasis on additional attributes that widen a base service: quality of information provided at stops and by means of interactive instruments (the Internet, mail), staff behaviour, etc. Moreover, it should be noted that significance of additional attributes for PT services consumers can be changed and a part of attributes can become the "obligatory" part of the base service (Lopatinskaya I. V., 2002).

\section{Methodology}

The main method of the study is observation that belongs to the methods of qualitative research and involves primary data collection by means of observation over objects under study and recording all facts significant in the context of set goals. The method of observation is used in marketing to solve a wide range of problems.

The feature of the study involves observation not over consumer, but over parameters of rendering transportation services, which according to the Customer influence consumers' perception of services. In this case one may suggest direct, open observation. On the other hand, the set task meets the technology of marketing studies named Mystery Shopping. The method of Mystery Shopping is usually used to study correlation of services rendering conditions: correlation of prices, service level, range of goods, goods quality, service culture, sales area arrangement and other aspects to corporate standards, and also to compare these aspects in competitive environment. At the same time, QUATTRO (QUATTRO, 1998) research project refers measurement of quality by the method of Mystery Shopper to "delivered" quality, which is evaluated by service provider. According to Pticin (Pticin I., 2011) the method of Mystery Shopping is used for transport and logistic services to estimate not consumer satisfaction, but the level of standards meeting.

With regard to features of transportation services rendering by public transport the combination of mystery shopper and parametric observation methods allow obtaining data, the analysis of which subsequently allows carrying out analytic work to evaluate transportation services quality. To provide the relevance of observation results it was suggested to carry out monitoring of routes of land urban passenger transport (LUPT) and underground over time interval 2-4 days in each wave of research. Despite the fact that observation refers to the methods of qualitative marketing researches, data obtained as a result of field work can be quantitatively evaluated and generalized. Parameter (indicator) is understood as quantitative properties of research subject. A set of parameters was defined for each service. These parameters are subject to objective measurement similarly to previously conducted research (Sidorchuk R. et al., 2015). Groups of research parameters are shown in Fig. 1.

\begin{tabular}{|c|c|}
\hline LUPT & Underground \\
\hline Navigation during riding land urban passenger transport, & $\begin{array}{c}\text { Speed of tickets buying in pay offices and slot-machines at underground } \\
\text { stations. }\end{array}$ \\
\hline $\begin{array}{c}\text { Cleanliness in a compartment of land urban passenger } \\
\text { transport, }\end{array}$ & Cleanliness in underground carriages. \\
\hline Wi-Fi performance in land urban passenger transport, & Air conditioner efficiency in underground railway carriages. \\
\hline Navigation at the stops of land urban passenger transport & Quality of mobile and Internet communications in underground carriages \\
\hline Condition of the stops of land urban passenger transport. & Cleanliness in lobbies of underground \\
\hline
\end{tabular}

Figure 1. Groups of research parameters

Evaluation of the majority of parameters was carried out based on the record of presence or absence of certain property by nominal (dichotomic) scale (availability of navigation tools in LUPT compartment, etc.). When studying some parameters ordinal scale was used to measure the gradation of parameter (measurement of electronic display work when 
evaluating navigation at LUPT stops). A number of parameters were measured quantitatively, by absolute scale (number of working ticket-issue and slot-machines and pay-offices; ticket buying time). This research was carried out by two waves: $1^{\text {st }}$ wave during the period from October 2, 2014 to October 10, 2014; $2^{\text {nd }}$ wave during the period from November 20, 2014 to December 15, 2014. 150 students, postgraduate students and professors of marketing department of Plekhanov Russian University of Economics took part in the field stage of the research. The choice of research periods was conditioned by Customer's requirement. Geography of study - Moscow.

For the purpose of the study LUPT transport facilities and stops, underground carriages and lobbies were sampled based on Customer's quotas. For each research wave means of transport that report to service passengers were sampled on the basis not less than five routes of each of bus depots, not less than three routes of each of trolley depots, not less than two routes of each of tramway depots. During the first research wave 199 routes of buses, 19 routes of tramways, and 50 routes of trolleys were examined. 6080 stops were studied on selected routes of LUPT. The sample for underground made up about $10 \%$ of carriages of operated depot - 460 carriages and 140 lobbies.

As previously mentioned the natural constraint of this research is not evaluation of service consumer's satisfaction or potential consumer's - private car's owner's satisfaction, but evaluation of chosen parameters. Moreover, quota sampling fails to consider statistical accuracy of research. Another constraint is insufficient time length between two waves of the research (determined by the Customer).

\section{Results}

The format of article keeps from particularizing all findings, that's why we provide results that reached most positive values for consumers of PT transportation service. Positive trend was tracked cross all indicators under study that allows concluding practical efficiency of the research in the context of interaction between researchers and customer's services providing solution of detected problems. The results of the examination of electronic display boards availability at the stops of land transport are shown in Fig. 2 (Indicator - Navigation at the stops of land urban passenger transport).

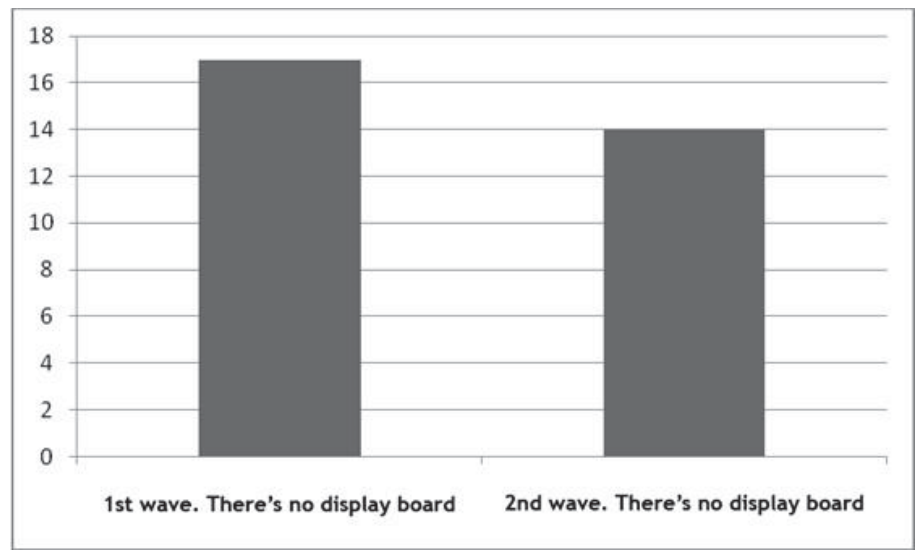

Figure 2. The results of the examination of electronic display boards availability at the stops of land transport

Subsequent to the results of the $1^{\text {st }}$ research wave it's shown that there was no display boards at $16,5 \%$ of examined stops of land PT. By the second wave this indicator decreased to 14\% of all stops of land PT.

Positive trend was noticed when studying working efficiency of display boards. During the $1^{\text {st }}$ wave they didn't operate at $16 \%$ of PT stops, and by the $2^{\text {nd }}$ wave this indicator dropped to $12 \%$ (Figure 3 )

Significant positive effect was revealed when studying efficiency of air conditioners in underground carriages (Indicator - Air conditioner efficiency in underground carriages). During the $1^{\text {st }}$ wave $65 \%$ of all air conditioners operated in underground carriages, by the $2^{\text {nd }}$ wave this indicator increased to $69 \%$ (Fig. 4). 


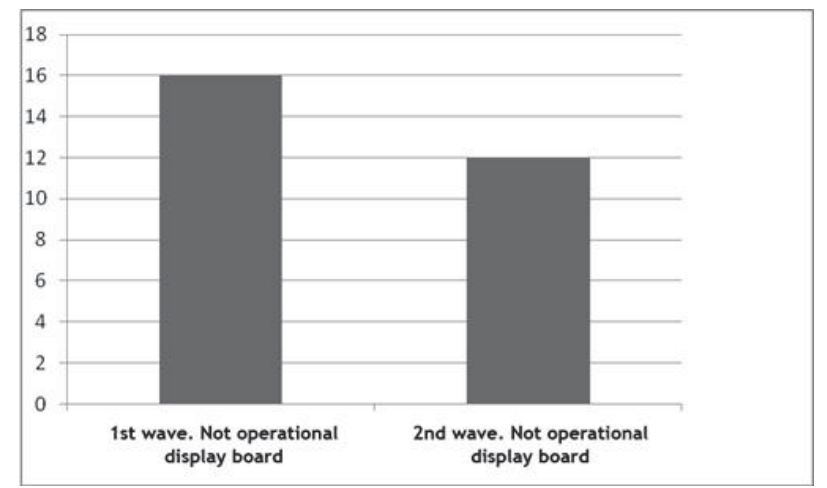

Figure 3. The results of the examination of electronic display boards operation at the stops of land transport

The growth of free WiFi availability in underground carriages demonstrated the most positive dynamics (Indicator Quality of Internet communications in underground carriages).

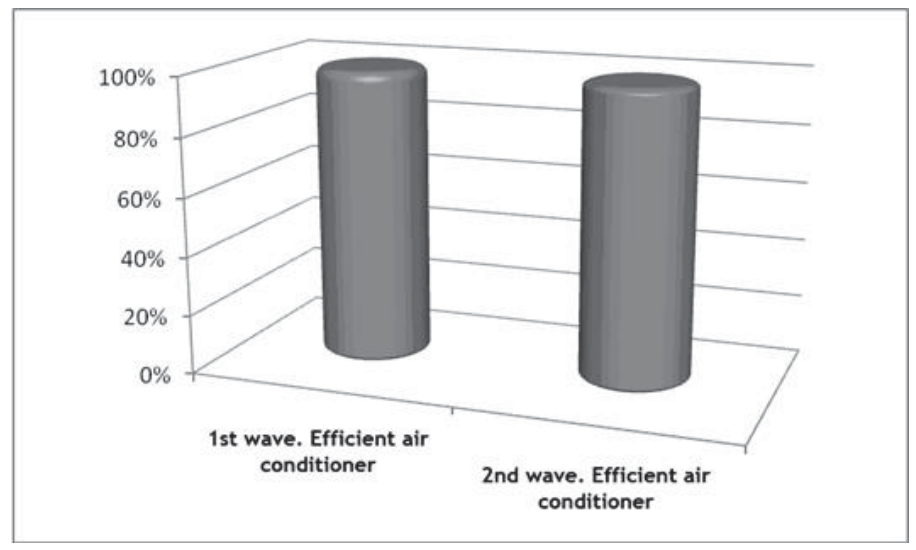

Figure 4. The results of the examination of air conditioners operation in underground carriages Indicator value changed from $55 \%$ of examined carriages to $83 \%$ (Fig. 5).

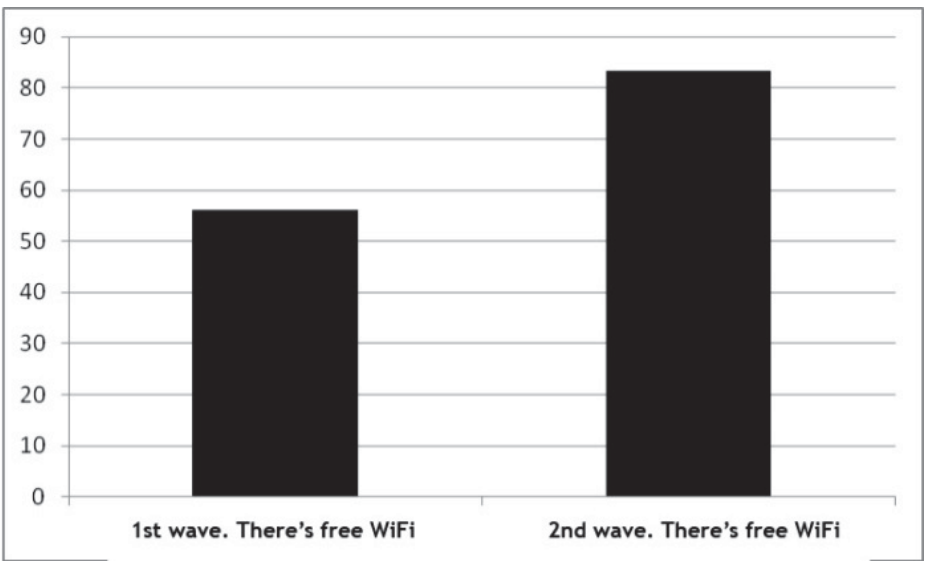

Figure 5. The results of the examination of free access to WiFi in underground carriages

Other indicators of the research: Navigation during riding land urban passenger transport, Cleanliness in a compartment of land urban passenger transport, Wi-Fi performance in land urban passenger transport, Condition of the stops of land 
urban passenger transport, Speed of tickets buying in pay offices and slot-machines at underground stations, Cleanliness in underground carriages, Cleanliness in lobbies of underground, Quality of mobile communications in underground carriages also demonstrated improvement.

\section{Conclusions}

As it can be seen from represented findings, carried out researches contributed to the improvement of parametric quality indicators of LUPT and underground. At the same time, the key mission of private cars' owners' shift to public transport by improving examined parameters quality is not performed. According to topnews.ru (2014) traffic jams in Moscow in 2014 attained a maximum, and on December 25 a record was achieved over the history of observation. We consider that suggested hypothesis of the research isn't confirmed and it's necessary to review approaches to the search for other ways contributing to private cars' owners' shift to public transport. In this regard the need for studying private cars' owners' values becomes apparent. Moreover, it's necessary to carry out evaluation of private motor transports' owners' perception of public transport service quality during the process of service rendering (at contact points): entry to PT terminal (underground stations, public transport stops), entry to PT transport means (underground carriages, bus compartments), in the process of riding and when coming out of PT. Moreover, the above-mentioned constraint of research methodology relating to statistical accuracy evaluation can be overcome in further measurements by applying multistage or stratified sampling that will allow increasing efficiency of research results. We suggest the need in further researches focused on studying private motor transport means' owners' values that will allow developing marketing program of PT use appeal enhancement.

\section{Acknowledgements}

The authors would like to express their gratitude to the students of marketing department, the professors of marketing department and entrepreniership and logistics department, who took part in the field study on information gathering. The authors express special gratitude to Moysov Viktor for practical assistance when interacting with the transport enterprises of the city of Moscow to provide carrying out of the study.

\section{References}

10-score traffic jams in Moscow on 25.12.2014 made a historical record. Retrieved from <http://www.topnews.ru/news_id_74119.html> Access date 30.01.2015

American Marketing Association. (2013). About AMA: Definition of Marketing. Retrieved from <https://www.ama.org/AboutAMA/Pages/ Definition-of-Marketing.aspx> Access date: 16.01.2015

Anastasie, D. (2012). Proiectul ENERQI - Monitorizarea şi îmbunătăţirea calităţii serviciilor de transport public, Transurb, 61, 4-6.

Costa, A., \& Fernandes, R. (2012). Urban public transport in Europe: Technology diffusion and market organization. Journal of Transportation Research Part A: Policy and Practice, Vol. 46, No. 2, pp. 269-284

Dragu, V. (2004). Aspecte specifice ale calităţii în transporturi, Buletinul AGIR, 3, 104-107.

Eboli, L., \& Mazzulla, G. (2009). A new customer satisfaction index for evaluating transit service quality. Journal of Public transportation, 12(3), 21-37.

Evans, M., Jamal, A., \& Foxall, G. (2006). Consumer behaviour. John Wiley\&Sons Ltd, Chchester, England, 404 p.

Fox, K. F. A., Skorobogatykh, I. I., \& Saginova, O. V. (2005). The Soviet evolution of marketing thought, 1961-1991: From Marx to marketing. Marketing Theory, Vol. 5, No. 3 283-307. http://dx.doi.org/10.1177/1470593105054899

Fox, K. F. A., Skorobogatykh, I. I., \& Saginova, O. V. (2008). Philip Kotler's influence in the Soviet Union and Russia,European Business Review, 2, 152-176. http://dx.doi.org/10.1108/09555340810858298

Friman, M., \& Felleson, M. (2009). Service supply and customer satisfaction in public transportation: the quality paradox. Journal of Public transportation, 12(4), 57-69.

Iancu, A. (2010). Marketing for the public transport <http://www.apas.admpubl.snspa.ro/handle/2010/141>. Access date 16.11.2015

James, S. (2001). Put the passenger first in integrated transport. International Railway Journal, 9, 15-19.

König, A. (2002). The Reliability of the Transportation System and its Influence on the Choice Behaviour - Paper presented at the $2^{\text {nd }}$ Swiss Transport Research Conference, March 20-22, Monte Verità/Ascona.

Kotler, P. \& Lee, N. (2006). Marketing in the public sector. A roadmap for improved performance. Wharton School Publishing.Pearson Education.

Liksutov, M. (2014). The number of cars on Moscow roads exceeds acceptable value by 500 thousand. Retrieved from <http://vm.ru/news/2013/11/26/kolichestvo-avtomobilej-na-moskovskih-dorogah-na-500-tisyach-previshaet-dopustimoe224364.html?page=1082> Access date 11.04.2014.

Lopatinskaya, I. V. (2002). Loyalty as main indicator of banking services consumers retention. Marketing v Rossii i za rubezhom, 3(29), 
20-32. Moscow: Finpress.

Nevrela, J. (2008). Quality in passenger railway services. In: Transportation and Land Use Interaction Conference Proceedings, Ed. Polytechnic Press, pp. 449-463.

Pticin, I. (2011). The methodology of data collection about public transport service quality. Proceedings of the 11th International Conference "Reliability and Statistics in Transportation and Communication" (Re/Stat'11), 19-22 October 2011, Riga, Latvia, 155164.

QUATTRO (1998). EU's 4th framework programme for research, technological development and demonstration. Project "Quality approach in tendering/contracting urban public transport operations. Final Report. Synthesis and recommendations", Retrieved from http://www.transportresearch.info/Upload/Documents/200310/quattro.pdf Access date 20.10.2014

Raicu, Ş. \& Dragu, V. (2012). Pentru un transport public mai atractiv. Transurb, 61, 34-40.

Region rating by the number of cars per 1000 residents is made <http://www.zr.ru/content/news/628830-sostavlen-rejting-regionov-pochislu-avtomobilej-na-1000-zhitelej/> Access date 11.04.2014.

Sidorchuk, Roman \& Efimova, Dariya \& Lopatinskaya, Irina \& Kaderova, Venera (2015) Parametric approach to the assessment of service quality attributes of municipal passenger transport in Moscow, Modern Applied Science; Vol. 9, No. 4; 2015, doi: 10.5539/mas.v9n4pxx

Sidorchuk, R. (2014). Integral effect estimation methods for a partner company of the participation in the coalition loyalty program. Research journal of applied sciences, Vol.9, pp. 947-951. http://dx.doi.org/10.3923/rjasci.2014.947.951

Steg, L. (2003). Can Public Transport Compete with the Private Car?, IATSS Res (Int Assoc Traffic Saf Sci), 27(2), pp. 27-35

Stopher, P., \& Jones, P. (2003). Transport Survey Quality and Innovation, Amsterdam: Pergamon.

The world capital of traffic jams. Retrieved from <http://www.gazeta.ru/auto/2013/11/08_a_5744077.html > Access date 11.04.2014.

Tobias, M., Waisman, J. \& de Paiva H. Jr. (2009). Service quality attributes in urban bus services: the experience of Belem - Para/Brasil. Urban Transport XV Conference Proceedings, Ed. WIT Press, pp. 405-417.

Webb, V. (2010). Customer loyalty in the public transportation context (Thesis of S.M. in Transportation), Massachusetts Institute of Technology, Cambridge, MA. 
ISSN 2039-2117 (online) ISSN 2039-9340 (print)
Mediterranean Journal of Social Sciences MCSER Publishing, Rome-Italy
Vol 6 No $3 \mathrm{~S} 3$ May 2015 